\title{
Good Vibrations, Strings Attached: The Political Ecology of the Guitar
}

\author{
James B. Greenberg \\ Department of Anthropology, University of Arizona, USA
}

Copyright $\bigcirc 2016$ by authors, all rights reserved. Authors agree that this article remains permanently open access under the terms of the Creative Commons Attribution License 4.0 International License

\begin{abstract}
This article examines the guitar trade (i.e. making, collecting and dealing) to examine the political ecology of the guitar from forests to construction: delving both into its environmental impacts and attempts to protect endangered species, it focuses on the impact of two pieces of legislation have on guitar making, the international guitar trade, and guitar ownership: the Convention on International Trade in Endangered Species of Wild Fauna and Flora (CITES); and the Lacey Act Amendments of 2008. In so doing, it examines the underlying problems (deforestation, endangered species, illicit trade in wood, and unfair trade advantages) that these pieces of legislation were meant to address; and the politicization of these efforts that has the US Congress deadlocked. This account also analyzes the practical difficulties that legal compliance presents, and finally examines what alternatives may exist.
\end{abstract}

Keywords Political Ecology, Deforestation, CITES, Illegal Wood Trade, Endangered Species, Lacey Act, Unfair Trade

\section{Political Ecology of the Guitar}

Fine guitars are made with a variety of different woods sourced from throughout the world-some species of which are comparatively common and plentiful; others which are exotic, rare, precious, and even endangered. While the former category includes spruce and cedar used for soundboards; the later category is comprised largely of tropical hardwoods, such as ebony, mahogany, and rosewoods. Typically, these woods flow from forests into the hands of guitar makers through long commodity chains that include loggers, local buyers, mills, middlemen, wholesalers, and exotic wood merchants. Because many of these species are threatened or endangered environmental concerns have given rise to not only to national laws governing their exploitation, but to international conventions and agreements governing their import and export. Those engaged in import or export of guitars must comply with these regulations and learn their key details. Here, I shall discuss two sets of these: The Convention on International Trade in Endangered Species of Wild Fauna and Flora (hereafter, CITES), and the U.S. Government's Lacey Act, enforced by the United States Fish and Wildlife Service (hereafter, USFWS).

Convention on International Trade in Endangered Species of Wild Fauna and Flora

CITES lists approximately 30,000 species of plants and animals in three appendices, depending on threat [1]. Appendix I includes species threatened with extinction. Appendix II "includes species not necessarily threatened with extinction, but in which trade must be controlled in order to avoid utilization incompatible with their survival." [2] Appendix III "contains species that are protected in at least one country, which has asked other CITES Parties for assistance in controlling the trade." [3] The some 1,200 threatened species listed in Appendix I require special CITES permits to import or export. [4] What listing in Appendix I may be illustrated with Brazilian rosewood (Dalbergia nigra) which owing to its tonal qualities and great beauty had been the first choice for the back and sides of fine classical guitars. In 1992, Brazilian rosewood was listed in Appendix I. This meant that any guitar made with any Dalbergia nigra after 1992 could not be imported or exported without a CITES permit-which would only be issued if it could be proven that the wood utilized in making it had been harvested prior to 1992 .

Spanish guitar makers were hit particularly hard by this listing. Because woods must be dried under controlled conditions over many years before they can be used, or it may crack, luthiers not only commonly bought supplies of wood many years in advance of use, but also believing that wood held its value even better than money, they considered wood to be form of long-term savings. The best bargains on wood were had by recycling wood from old furniture or by buying wood from other makers who either needed cash or were being sold after their death by their relatives. Unfortunately, this wood was rarely documented. Even if they it had purchased from wood dealers, few makers kept receipts for more than a few years. Following the listing of 
Brazilian rosewood on Appendix I, although there had been a short period during which people could register their wood, most makers were either unaware of this, or for a variety or reasons chose not to so. The upshot was Dalbergia nigra listing on Appendix 1, caught many makers with stock-piles of unregistered Brazilian rosewood that they could no longer legally export. However, as listing in Appendix I only applied to exports, makers still could use their Brazilian rosewood to make guitars; these could only be sold domestically.

As one might expect, games were played. Long before Dalbergia nigra was listed in Appendix I, because so many woods both in the Dalbergia family as well as unrelated species look very similar to Brazilian rosewood, many of these look-a-likes were passed off as true Dalbergia nigra. Even experts occasionally could be fooled, as the differences between some species can only be discerned under the microscope, and with closely related species may require chemical or DNA testing. The export requirements for CITES permits not so strangely encouraged makers to do just the opposite, and call genuine Dalbergia nigra one of these other woods. Enforcement in Spain was fairly lax up prior to 2002 when one very well-known builder in Madrid was caught reusing the same permit for the exportation of many guitars. So, the Guardia Civil (Spain's national police) began a two-year long investigation, and in October 2004, raided twenty-one guitar builder's workshops in Madrid and seized thirty-three tons of Dalbergia Nigra. Among the upshots of this crackdown, as one representative of the major wood import companies in Spain explained to me is that although their stocks of Dalbergia Nigra had been legally declared; and, despite having been given CITES certificates for them, nevertheless, their stocks of Dalbergia Nigra, were embargoed. Not because they had done anything wrong, but because authorities had no way to guarantee that their legal stocks could not be sold under the table and replaced by undocumented wood still circulating in the black market. Although this wood still legally belongs to them, but they cannot sell it, or even move it from one part of their warehouse to another without permission, which has not been forthcoming.

Faced with work involved to obtain CITES permits-guitar collectors and dealers have become increasingly leery of purchasing any guitar made with any dalbergia nigra components. While one might think that guitars made with Brazilian rosewood prior to 1992 would not fall under its regulations, this is only partially true. The USFWS makes three significant distinctions: Pre-Convention, Pre-Act, and Antique Musical Instruments. To import or export a guitar made prior to the listing of dalbergia nigra in 1992, proof must be presented that instrument was procured or made before this date. [5] If the guitar is less than 100 years old, its history of sale since December 28, 1973 must be documented; and, if it were imported into the United States after 1975, documentation of its importation also is required. [6] Anyone wishing to import or export an antique guitar made with materials that were manufactured or removed from the wild more than 100 years ago, must provide either documentation or expert appraisals of the instrument's age. [7]

As difficult as all this may sound, these regulations only describe the US side. For example, as one luthier from Spain explained who had to obtain CITES documents for on the antique guitar made in Granada in 1823 that he restored for a client overseas that first he had to go to the office that handles CITES to obtain the proper forms. As the guitar was over 100 years old, it qualified for Antique Musical Instrument Certificate of Exemption. He filled out the forms. However, as an antique guitar also needed a letter authenticating its age, so it had to be inspected by an approved expert. These documents then had to be sent to a regional office for approval; and, then forwarded to Spanish Ministry of Antiquities for their sign off that the guitar was not a national treasure, and so was eligible for export. The process involved numerous visits to local offices, petitions to the central office, and so took over three months.

The issue of restoration can be a tricky business. This guitar required replacing a strip of the top (made of spruce), but had it involved Brazilian rosewood, adding even a bit of new dalbergia nigra could have invalidated the claim to the CITES antique exemption. As this was explained to me had this 1,823 guitar been missing its ivory nut, if the luthier were to replace it with a piece of 10,000 year old mammoth ivory, under CITES the moment the luthier fashioned it into a new nut, legally the mammoth ivory became a new piece of ivory- and not only illegible for a permit, but grounds for confiscation.

\section{The Lacey Act}

Aside from customs declarations, CITES permits had been the principle paperwork that guitar importers routinely faced. Because of the time-consuming nature of obtaining CITES permits, many guitar dealers avoid importing guitars made with woods that required these permits unless the seller can readily provide them. In 2008, Congress amended the Lacey Act of 1900 that was originally passed during the McKinley administration as part of an effort to protect wildlife from poachers. The Lacey Act prohibits trade in any wildlife, fish, and plants that are illegally taken, possessed, transported, or sold. Although the Lacey Act was originally intended for use within the United States to combat the interstate market for such species, the 2008 amendments expanded its scope not only to be international, but also to include all the species listed in CITES and in the Endangered Species Act of 1973. One of the primary motivations for the 2008 Amendment was to control illegal logging, and to protect the US timber industry from foreign competition, it was then extended to cover all commodities made of wood, including since September 1, 2010, guitars irrespective of the size of the shipment or when the guitar was made.

The politics behind the Lacey Act stems from a twofold problem. First, almost half of the timber now shipped globally is destined for China where it is transformed into flooring, furniture, and other wood products. Although this 
increased the competition US manufactures of these products faced, China's voracious appetite for wood, apart from its ecological costs, is claimed to be fed by huge quantities of illegally harvested wood from around the world, monies from which help finance criminal, militia, and terrorists groups. According to the estimates of the Organization for Economic Co-operation and Development, the UN Office on Drugs and Crime, United Nations Environment Program, and INTERPOL constitutes 10 to 30 percent of the global timber trade, valued at $\$ 30$ to $\$ 100$ billion annually. In some tropical countries, an estimated 50 to 90 percent of the wood sold is suspected to come from illegal logging. [8] The effect of the 2008 amendments to the Lacey Act has been to make it illegal to import, export, sell, receive, acquire, or purchase a plant in interstate or foreign commerce that was "taken, possessed, transported, or sold in violation of any limitation under any law or regulation of any state, or under any foreign law, governing the export or transshipment of plants." [9]

While the intent of both CITES and the Lacey Act is clearly laudable, there has been a good deal of push back in the guitar trade, and among music merchants generally. The National Association of Music Merchants (NAMM) has made the Lacey Act a priority item, and has lobbied hard to have certain provisions of the Lacey Act amended. One of the problems with the Lacey Act is that is that anyone traveling abroad, even with their own guitar, could run into problems, [10] but here the devil is in the details. No matter when a guitar was made the amended Lacey Act of 2008 requires the importer to provide a Lacey declaration that contains a list of each species an item made of wood contains including its common name, scientific name, country of harvest, and quantity (e.g. percentage of weight). One guitar detained by USFWS under the Lacey Act illustrates the problem. There were two problems with this shipment. Importers must have an USFWS import-export license, a simple matter of applying for this license and paying the required fee. The other problem did not concern wood, but a small quantity of abalone used as decoration. The shell itself was perfectly legal, however, under the provisions of Lacey, the USFWS required the declaration of all wildlife species, including specific species and country of origin for their database, and so would not release the guitar until this information was provided. Ultimately, this required calls to the maker, to his supplier, to a distributor in Japan, and to a middleman in New Zealand, the country of origin, who fortunately supplied the species.

Under the Lacey Act, the importer by signing the required declaration certifies that the declared list of woods from which an item was made contains only woods that were legally harvested and sold under the laws of their countries of origin. The penalties for Lacey Act violations include: 1) forfeiture; 2) for misdemeanors by a year in prison and a $\$ 100,000$ fine where in the exercise of 'due care' an individual or corporation should have known that the plant species was illegally harvested, transported, or sold; 3 ) for felonies punishment includes five years in prison and a $\$ 250,000$ where there is a knowing violation, meaning illegality, and knowledge of the facts, even if not of the specific law violated. [11]

Though a particular guitar may only contain a few species of wood, there are hundreds of species of wood in the world used in guitar making. Under the Lacey Act the importer is held responsible to know not just the commodity chains for each species, but also the laws of the countries of origin. The practical problem, given the prevalence of illegal logging, has been how to certify that woods have been legally harvested and sold. One promising solution developed by The Forest Service Council (FSC), and promoted as part of its efforts to promote sustainable forestry is its Chain-of-Custody Certification which certifies the path products take from their harvest in forests all along the supply chain. Unfortunately, this is a voluntary program, and FSC certificates are not available for many species.

Even companies that have the resources to hire full-time experts to deal with compliance issues have run into legal difficulties. The best-known example has been Gibson Guitar Company, a major US manufacturer of guitars. In 2009, using the Lacey Act, the USFWS raided Gibson, and seized ebony from Madagascar. Gibson came onto the USFWS radar, when the Department of Justice found emails from 2008 and 2009 in which Gibson employees were discussing the "grey market" nature of ebony from Madagascar that a German wood dealer had, and their plans to buy this wood. While Gibson maintained that it had been a clerical error that CITES documents for Dalbergia nigra were mistakenly used to import this ebony, fearing criminal convictions, they settled the matter in 2012, and agreed to pay $\$ 300,000$ in fines as well as to donate $\$ 50,000$ to the National Fish and Wildlife Foundation. They also forfeited the seized ebony, whose value was about that of the fines. [12].

In 2011, the USWFS again raided Gibson, this time seizing some Indian rosewood. Although this rosewood had FSC certification, and the Indian government had approved its export-under the Lacey act, it did not meet the standards that Indian law set for its export which required rosewood to be milled in India to a thickness of $6 \mathrm{~mm}$ or less. The seized wood was a full centimeter thicker than Indian law specified. Gibson was raided this time, not because they had violated Indian law, but because under the Lacey Act, it is the US courts which decide the interpretation of applicable foreign laws.

\section{Politics and the Lacey Act}

The Gibson raids were perhaps over the top. The USFWS sent armed federal agents to execute the search warrant, who entered the factory like a SWAT team wearing bullet proof-armor and with their guns drawn. They seized woods, computers, and papers, shut down production, and sent employees home. The Gibson raids sparked a political uproar among right-wring, and tea-party conservatives-who saw Lacey as another example of government interference 
and over-regulation, and alleged that these raids were yet another example of Obama's abuse-of-power; and, further insinuating that Gibson was targeted because its' CEO, Henry Juszkiewicz had made campaign donations to Republicans, and that labor union were behind all this since Tennessee is a right-to-work state and Gibson is a nonunion shop. The Gibson raids in combination with a certain murkiness about what the Lacey Act covers clearly sent panic through the industry. Individual guitar makers-without staff to devote full-time to compliance issues-worried that the Lacey Act is retroactive, and so they could be "forced to prove the provenance of wood they acquired decades ago." [14] Guitarists traveling abroad worried that their instruments might be confiscated, and wondered what they must do to document them. These concerns prompted the National Association of Music Merchants (NAMM) in 2011 to join the Lacey Act Defense National Consensus Committee (a group representing companies, associations, and organizations as well as environmental groups) whose expressed intent was to create a new standard designed to provide a defense against Lacey liability, and to lobby congress to make amendments to the Lacey Act that would "clarify its regulatory guidelines, enforcement rules, and appropriately define what constitutes "due care" under the act.” [15]

Responding to these lobbies, Bills were introduced both in the U.S. House of Representatives, and in the U.S. Senate. The first of these, H.R. 3210, titled "Retailers and Entertainers Lacey Implementation and Enforcement Fairness Act" or the "RELIEF Act" was introduced on October 14, 2011, and was assigned to the House Committee on Natural Resources. This bill proposed to modify the Lacey Act's 2008 amendments-noting that they "were overly broad and their enforcement ... could criminalize actions of a good-faith owner, purchaser, or retailer of a plant or plant product, subjecting them to penalties that include forfeiture, fines, and imprisonment." [16] The Bill further proposed that "Sanctions for violating the 2008 amendments should be proportional to the ... violation. An individual who is not in the commercial shipping business should not be held to the same standard of compliance under that Act," [17] and continued on to observe that "individuals fear that they risk incurring those penalties by merely owning or traveling with a vintage musical instrument, antique furniture, or another wood product." [18] The Bill further proposed that "Declaration requirements for plant products imported or manufactured prior to May 22, 2008, are unreasonable since the sourcing of plant products was not previously required by law." [19] On June 17, 2012, the House Committee on the Natural Resources voted to order the Bill to be Reported (Amended) by Yeas and Nays: 25 - 19 with all Republicans voting Yea, and all Democrats and one republican voting no. Despite the Committee's recommendation, the bill died in congress.

On March 8, 2012, H.R. 4171 (The FOCUS Act) also called the "Freedom from Over-Criminalization and Unjust Seizures Act of 2012" [20] was introduced in Congress "to amend the Lacey Act Amendments of 1981 to repeal certain provisions relating to criminal penalties and violations of foreign laws, and for other purposes." [21] This Bill targeted the previsions in the 2008 Lacey Act amendments that required the U.S. courts to enforce foreign laws applicable to legal logging etc, proposing specifically to strike from its language "in violation of any foreign law." [22] House bill H.R. 4171 also proposed to reduce the penalties prescribed under the 2008 amendments from criminal to civil sanctions in most cases as well as reducing fines, and setting maximums. Although this bill also went nowhere, and died in Congress, the lobbing of congress by the Lacey Act Defense National Consensus Committee has continued. On April 21, 2015, Senate bill S. 1019, as known as the "Freedom from Over Criminalization and Unjust Seizures Act of 2015," [23] with essentially the same recommendations as S.R. 4171 was introduced by Senator Rand Paul of Kentucky, and was referred to the Senate Committee on Environment and Public Works.

Unfortunately, partisan politics has overshadowed whatever merit these bills may have, with Republicans largely for them, and Democrats mostly opposed. The Republican view of Lacey is that it is both overly broad and places an enormous, costly, and unfair burden on the businesses involved, exposing them to criminal and civil penalties under foreign laws even for things others might have done, but also exposing ordinary, law abiding people to such sanctions. Democrats and others (including a diverse group of conservationists, timber industry, labor unions, wood product users) who oppose these amendment bills see them as attempts to gut the environmental protections the Lacey Act provides against the illegal logging which they see as partly responsible for the pillaging the world's forests, decimating of wildlife, and contributing to climate change, but also as hurting manufacturing jobs in the United States. They also assert that many illegal logging is closely tied to illegal drugs, terrorism, slavery, and the exploitation of child labor. [24] Unfortunately lost in this political rhetoric is that there are measures of truth on both sides, but because of political games these problems remain unsolved.

\section{3. "Due Care" under Lacey}

What the Gibson raids highlight are the difficulties that 'due care' under Lacey entails. While under Lacey, the gold standard is to ensure that woods have been legally harvested and exported in accordance with their countries of origin, the rub is that it is U.S. courts that interpret the underlying foreign law, and the statutes in question need not be of a criminal nature or even actively enforced by the foreign country, but merely on their books. Moreover, even if a third party is responsible for illegal logging or sale of such woods, Lacey also holds importers responsible' under the theory that had they exercised 'due care' they should have known because a reasonable person in these circumstances would undertake certain steps to do their best to insure the 
transaction is lawful. The standard of 'due care,' however, is not spelt out completely, but rather rests on a theory of expert knowledge, recognizing that different categories of people have different degrees of knowledge and responsibilities. Under this standard; for example, guitar manufacturers as professionals should know that CITES permits are required for particular woods, and if they were to import or export a guitar that contained these woods without insisting on the proper permits, they would have failed to exercise 'due care'. Beyond this, 'due care' is a matter of common sense, and following best practices.

Common sense, for example, would raise a red flag if a commodity is being offered at significantly below the going market price, or if the seller insists on cash, or proposes usual methods of transaction, or can't or won't provide proper paperwork, or offers documents that are inaccurate, invalid, or otherwise, suspect, or can't provide rational answers to routine questions. Best practices regarding Lacey declarations, at least those suggested by the US Department of Agriculture (USDA) include asking foreign suppliers for Genus and Species data, checking these with botanical databases and resources such as the GRIN Taxonomy to confirm the validity of scientific names and geographic distribution. They further recommend checking with the proper foreign government authorities to confirm that companies are licensed, certified, and operating legally, and request they provide pertinent laws. Most importantly, one should keep complete records of ones efforts, and when in doubt call (USFWS or APHIS). [25]

Although these suggestions seem like common sense, especially since one can be charged for crimes others have committed, and can be prosecuted for violations of foreign law, there is something Kafkaesque about the Lacey Act, particularly given its vagueness on what constitutes 'due care.' If one can be held responsible under foreign laws, the practical question is what constitutes due diligence when; for example, Indonesia alone "has more than 900 laws, regulations, and decrees that address timber harvesting and processing." [26] The problem that Lacey tries to address is that corruption in some foreign countries is widespread, and official documents and legal procedures may be used to hide the facts. [27] Under Lacey it is U.S. courts that interpret and enforce any applicable laws on the books of foreign nations, whether they enforced in these countries or not. Since the facts may be well hidden by corruption, by legal simulations, even by licenses, certifications, bills of sale, there is no guarantee that best practices of the sort outlined above may be sufficient due diligence.

Guitar dealers, luthiers, manufacturers, guitarists, and others with intimate relationships to others within this industry suggest that they rely on information and gossip that circulates within their circles, and that most transactions are based on trust established through repeated dealing, and they are very leery of offers from people they do not know well. Among those with whom trust has been established information is shared widely and freely, especially when it comes to matter of reputation. This sharing information in fact constitutes their best practice.

\section{Issues of Enforcement}

From the perspective of political ecology, although the intent of the Lacey Act's provisions is meant to protect forests and wildlife, the political realities are complex. The Lacey Act has a "house divided" at least on Capitol Hill, with little sign that either party will compromise. The basic enforcement problem; nevertheless, remains how to insure the legality of woods harvested and sold; so, the technical issues that must be solved are how to document the timber that is cut as it is logged, transported, cut, and sold. This entails examining the kinds of documentation, surveillance, and enforcement that would be required as timber moves along the commodity chain and is transformed into lumber and wood products.

At the risk of stating the obvious, as wood moves up the commodity chain, more and more players are involved, necessarily increasing the costs of documentation, surveillance, and enforcement. Logically, the most efficient use of resources would begin where there a fewest players, at the level of forest extraction, instead of at the border where the number of players, and the costs of enforcement are staggering. Unfortunately, the real politics are that there seems to be deep structural issues that stand against this logic. Poor countries frequently lack the economic resources to effectively intervene. Often in the countryside of developing nations, because the livelihoods of the poor depend on forests and forest products, enforcement too often comes at their expense. [28] Moreover, the temptation for poorly paid officials to engage in corruption is great. The literature is replete with accounts of corrupt officials letting loggers cut more trees than allowed, of falsification of land boundaries, of allowing timber trucks to carry heavier loads than permitted. [29] As one moves up the commodity chain to lumber milling again there are opportunities for regulatory oversight-as there are fewer lumber mills than loggers- but there are also plenty of ways of evading controls: sawing up of unregistered trees, reusing permits, and so on. Certainly, the number of players involved in exporting logs and lumber is many times smaller than those engaged in manufacturing products with wood, and even less than for retailers or ultimately for consumers [30] again logically would seem to be nodes in the commodity chain where enforcement efforts could be cost-effective.

At present, given the reputed size of the black market in wood, clearly enforcement has been ineffective. And while admittedly illegal acts may occur at any of these steps along the supply chains from forest to finished products, because the Lacey Act intervenes at a very late stage in the supply chain, it requires massive and costly efforts-and arguably may not be any more effective. According to a US House committee report in 2013, over a million Lacey declarations are filed each month, yet the USFWS office for law enforcement whose budget for fiscal year 2012 was only 
\$62.1 million has only 219 agents and 143 inspectors [31]. These budget limitations in practical terms mean that investigators conducted into 12,745 cases, of which 2,505 were related to the Lacey Act. [32] Whatever the impact of these cases may have on curbing illegal trafficking of species must be balanced against efforts and cost of filing over 12 million declarations a year. Unfortunately, there are no comparable figures or simple way to calculate compliance costs. To illustrate the problem, while it may take an hour for a guitar dealer to fill out the Lacey Declaration (not counting due diligence efforts) to import one guitar, major companies like IKEA might generate a 1000 page Lacey document to support one shipment, and calculate that it costs them 25 person years annually to complete Lacey declarations forms alone. [33] In fairness, to do a real cost-benefit analysis of Lacey minimally would also have to consider its impacts on the U.S. timber. The premise being that illegal logging depresses market prices, and so hurts revenues for legal logging operations both here and abroad. According to one such industry calculation, illegal wood depresses the value of legally harvested woods from seven to sixteen percent, and costs the U.S. forest product industry approximately $\$ 1$ billion annually. [34] Moreover, studies also show that illegal logging is associated with corruption, and the evasion of taxes and fees on woods, costing governments around the world some $\$ 15$ billion in lost revenues [35].

The bills introduce in the US congress have to amend the Lacey Act so far have focused solely on legal remedies, such as eliminating enforcement of foreign laws, eliminating individual criminal liability, setting limits on fines. Unfortunately, because of the way political interests have lined up on this issue along party lines, no real political progress has been made on these issues. The dilemma is a familiar one in congress-"if your only tool is a hammer, everything looks like a nail." Although legislative approaches for dealing with this dilemma seem to be emeried in politics, the technical questions remain how to how to regulate (license and enforce) timber exaction; and how to track inventories of wood (in our case is from forest to woods luthiers buy to their content in guitars sold to consumers). This suggests that the solution may be as much a technical question as a legal or political one. [36]

\section{Technical Dimensions of Control over Forests and Forest Products}

The technical side is of how regulate and track wood and its derived products as they move along commodity changes is actually straight forward. It would require setting up a centralized title and registry system which would issue unique registered identification numbers for trees that could add additional codes as logs are transformed into lumber; then, as lumber is transformed into products, assign unique numbers and codes to batches. In theory, with such a system one could track wood from logs to guitars-and even provide a title to the guitar owner that would list of woods with registry numbers by species. Such systems are hardly novel. We find examples in the central registries of Departments of Motor Vehicles to tile cars, airline ticketing, and inventory control software. Logging companies, timber mills, lumber yards already use such software to track their inventories using bar codes or chips. The United States Department of Agriculture (USDA) uses similar systems to track imported into the US, and moving through our food supply systems. (37) So, why hasn't this been done?

Although there have been steps in this direction, most notably by the Forest Stewardess Council (FSC), this is a voluntary program that depends on consumer demand for certified wood, and so lacks the clout of governmental enforcement. [38] Albeit a few guitar manufacturers now offer models entirely made with FSC woods [39]unfortunately, most of the fine tone woods are not yet available through its channels so many makers continue to source woods through other venues. Moreover, FSC certification may not guarantee that woods are Lacey Compliant as Gibson discovered when Federal agents also seized FSC certified woods during their 2011 raid [40].

As we have already noted, the choice in 2008 to amend the Lacey Act of 1900 seems to have been driven by increasing loss of U.S. market shares particularly in the wood flooring and hardwood plywood trade to foreign competition, particularly from China, but also from Brazil, Canada, Indonesia, Malaysia, and Russia. [41] Since these countries are members of the World Trade Organization (WTO), imposing import duties or other fees and direct actions to inhibit trade would violate WTO rules and agreements meant to protect free trade. Under industry pressure to remedy the situation, Congress looked for non-trade based barriers that might be imposed, and found the legal foundations for them in the Lacey Act which protected wild flora and fauna from illegal exploitation. At the time, this looked like a win both to environmental and business groups, and to US security interests who sought to dampen the black market in woods which they felt played a role in the financing of terrorism. The rub was that to qualify non-trade barrier, the Lacey Act had to broadly apply to all the species under USFWS protections not just those used in wood flooring or in plywoods, meaning it had to be applied all wooden items, including guitars. As other commercial interests began to be gored, political attempts to amend the Lacey Act has pitted environmental and business interests against one another along party lines, deadlocking such efforts. Although the Act's stated purpose remains protecting the world's flora and fauna from illegal exploitation, the protections it provides from foreign competition to important sectors of US market are not exactly hidden. So even if technical solutions such as registries might be more efficient that the Lacey Act as means of addressing the problems of illegal logging or the suppression of the black market trade in woods-given the broad scope of Lacey Act's underlying trade objectives, for the present its enforced at the border seems not destined to change. 


\section{Conclusions}

The political ecology of commodities has tended to focus on simple commodities - natural resources, crops, animals, and specific species of wildlife. Commonly the stories told are tales of the ecological consequences of human activities that raise issues of sustainability and management, or alternatively delve into how larger sets of political and economic relations shape the exploitation of an ecosystem or of particular species [42]. This article takes on what is clearly a complex commodity as its components may be sourced from throughout the world. Some of the woods used are threatened and endangered species extracted from forests, others came from sustainably managed forests or are grown on plantations. Faced with such complexities, few have chosen to wade into these deep waters. Even those who have tried are usually forced to simplify their research design to make it manageable. Jose Martinez-Reyes, for instance, chose to focus his research on one guitar model, made by one U.S. manufacturer out of mahogany. Even with these restraints, he found that there were several species of mahogany, one of the species of mahogany was on the CITES list of threatened species in its native Honduras, and so the company sourced its wood from Mexico, Guatemala and Fiji [43]. Although this article does not pretend to address all the complexities involved in exploitation or processing of woods, or examine sundry commodity chains that are part of the bigger picture, what it is does reveal is that a guitar is entangled in a complex political ecology involving enormous sets of stakeholders, political actors and interest groups whose politics influence the workings of these commodity chains; and, that if we want to understand the political ecology of complex commodities, this is the political landscape that must be traversed. While this article focuses on the politics behind a couple of pieces of legislation affecting the guitar trade-- CITES and Lacey, other countries have or are instituting similar measures to protect endangered species; and, clearly behind these lie equally intriguing and complex politics, the consequences of which are likely to spill across vast terrains.

\section{REFERENCES}

[1] Furlett, Joseph. 2015. The insufficiency of the Musical Instrument Passport Program Under CITES and the Lacey Act: The Need for a Centralized Wood Title Certification System for Manufactured Wood Products and Wooden Musical Instruments, The John Marshall Law Review, Vol 48, Issue 2, pp-494-537.http://repository.jmls.edu/cgi/viewcontent.cgi?art icle $=2253$ \&context=lawreview (Accessed January 18, 2016).

[2] Convention on International Trade in Endangered Species of Wild Fauna and Flora. Official Website. .https:// www.cites.org/eng/disc/how.php (Access January 18, 2016).

[3] Ibid.
[4] Wikipedia. CITES.https://en.wikipedia.org/wiki/CITES\#Appendix_I (Accessed January 18, 2016).

[5] Furlett, Joseph. 2015, p. 502.

[6] Ibid. p. 503.

[7] Ibid. p. 502.

[8] Daniels, Alfonso 2009. Battling Siberia's devastating illegal logging trade. BBC World News. 27, November. http://news.bbc.co.uk/2/hi/8376206.stm (Accessed on February 8, 2016). p. 1-4.

[9] U.S. Customs and Border Protection. Rulings SEC. 8204. Illegal Prevention Portal. Prevention of Illegal Logging Practices.http://www.cbp.gov/document/rulings/section-8204 -prevention-illegal-logging-practices (Accessed February 9, 2016).

[10] The North American Association of Music Merchants has been actively lobbying congress on this issue. See Furlett 2015 for a more detailed discussion of the issues involved.

[11] U.S. Department of Agriculture. 2013 Lacey Act Primer and Updates. United States Department of Agriculture Animal and Plant Health Inspection Service Plant Protection and Quarantine. August, p. 8. https://www.aphis.usda.gov/plant_h ealth/Lacey_act/downloads/LaceyActPrimer.pdf (Accessed on February 9, 2016).

[12] Genova, Patrick. 2013-2014. Good Vibrations; The Push for New Laws and Industry Practices in American Instrument Making. William and Mary Environmental Law and Policy Review, Vol. 38:195-220, Pp. 201-204.

[13] SWAT is an abbreviation for Special Weapons and Tactics.

[14] Havighurst, Craig. 2011. Why Gibson Guitar was Raided by the Justice Department. The Record: Music News from NPR. September 6th.http://www.npr.org/sections/therecord/2011/0 8/31/140090116/why-gibson-guitar-wasraided-by-the-justicedepartment (Access on September 9th, 2016).

[15] U.S. Department of Agriculture. 2013. Lacey Act: Frequently AskedQuestions.https://www.aphis.usda.gov/plant health/La cey_act/downloads/faq.pdf (Accessed February 9th, 2016), p.3

[16] U.S. House of Representatives, H.R.3210 - 112th Congress (2011-2012). [Report No. 112-604].https://www.congress.go v/bill/112th-congress/house-bill/3210/text (Accessed February 9, 2016).

[17] Ibid.

[18] Ibid.

[19] Ibid.

[20] U.S. House of Representatives. 112th Congress H.R. 4171 Freedom from Over-Criminalization and Unjust Seizures Act of

2012.https://www.govtrack.us/congress/bills/112/hr4171/text (Accessed February 9, 2016)

[21] Ibid.

[22] Ibid.

[23] U.S. Senate, 112th Congress, S. 2062. Freedom from 
Over-Criminalization and Unjust Seizures Act of 2012. February 2,2012.https://www.govtrack.us/congress/bills/112/ s2062/text (Accessed February 9, 2016).

[24] Schmidt, Jake. House Committee Votes to Allow Illegal Loggers to Pillage World's Forests. Huffington Post. August 8, 2012.http://www.huffingtonpost.com/jake-schmidt/house-co mmittee-votes-to- b 1579612.html (Accessed January 28, 2 016).See also World Wildlife Fund. 2008 Illegal Wood for the European Market: An Analysis of the EU import and export of illegal wood and related products.

[25] U.S. Department of Agriculture. 2013 Lacey Act Primer and Updates. United States Department of Agriculture Animal and Plant Health Inspection Service Plant Protection and Quarantine. August, p. 8. https://www.aphis.usda.gov/plant h ealth/Lacey_act/downloads/LaceyActPrimer.pdf (Accessed on February 9, 2016). p. 10-14.

[26] Sheikh, Pervaze A. 2014. The Lacey Act: Compliance Issues Related to Importing Plants and Plant Products. Congressional Research Service. CRS Report for Congress. 7-5700 www.crs.gov R42119.http://nationalaglawcenter.org/wp-cont ent/uploads/assets/crs/R42119.pdf. (Accessed February 3, 2016), p. 21.

[27] Genova, Patrick. Op Cit. p. 223. See also World Wildlife Fund. 2008 Illegal Wood for the European Market: An Analysis of the EU import and export of illegal wood and related products.

[28] The dependence of the poor on forests in many parts of the world for their livelihoods often puts them in conflict with commercial and environmental interests. See Mustafa Bayrak, Mucahid, Tran Nam Tu, and Paul Burgers. 2013. Restructuring space in the name of development: the socio-cultural impact of the Forest Land Allocation Program on the indigenous Co Tu people in Central Vietnam. Journal of Political Ecology Vol. 20:37-52. See also Robert Emanuel, and James B. Greenberg. 2000. Lluvia Enojada-Tyoo Kuasi' The Political Ecology of Forest Extraction in the Sierra Chatina, Oaxaca, Mexico. Journal of Political Ecology, Vol 7 pp. $43-63$

[29] Eberhart, Stephanie. 2013. The Lacey Act Amendments and United States Policing of International Trade. Houston Journal of International Law Vol. 35, (2)397-430, Pp. 406-413.

[30] Elias, Patricia. 2012 Logging and the Law How the U.S. Lacey Act Helps Reduce Illegal Logging in the Tropics. Union of Concerned Scientists, April, Table 2. Where Illegal Forestry activities Occur along the Supply Chain, p. 6. http://www.ucsusa.org/sites/default/files/legacy/assets/docum ents/global_warming/illegal-logging-and Lacey-act.pdf (Accessed Feb. 3, 2016).

[31] U.S. House of Representatives, Subcommittee on Fisheries, Wildlife, Oceans, and Insular Affairs, Oversight Hearing on the 2008 Lacey Act Amendments Part 1 and 2, May 16, 2013; July 17, 2013. Washington: U.S. Government Printing Office Serial No. 113-16.https:/www.gpo.gov/fdsys/pkg/CHRG-11 3hhrg80980/html/ CHRG-113hhrg80980.htm (Accessed Feb. 3, 2016).

[32] Sheikh op. cit. p.9.

[33] Ibid. p. 13.

[34] Seneca Creek Associates and Wood Resources International.
2004. Illegal Logging and Global Wood Markets: The Competitive Impacts on the U.S. Wood Products Industry, prepared for the American Forest \& Paper Association, October p. $2 ; 26$.

[35] Sheikh op. cit. p. 13

[36] The underlying problem here is one of institutional failure. See Acheson, James M. 2006, Institutional Failure in Resource Management. Annual Review of Anthropology, Vol 35:117-134. Deforestation is not caused simply by illegal logging or even corruption, but by deeper political and economic processes that push particular government policies and practices (See also Munro, Paul G. 2009. Deforestation: constructing problems and solutions on Sierra Leone's Freetown Peninsula. Journal of Political Ecology, Vol 16: 104-122 for an example.

[37] Alvarez, Robert. R. 2001. Beyond the Border: Nation State Encroachment, NAFTA, and Offshore Control in the U.S. Mexican Mango Industry," Human Organization, 60: 121-127.

[38] The FSC is one among many such efforts. See Klooster, Dan. 2006. Environmental Certification of Forests in Mexico: The Political Ecology of a Nongovernmental Market Intervention. Annals of the Association of American Geographers. Sept. 96(3):541-565, Pp. 541-542.

[39] Some of the manufactures offering guitar models made entirely of FSC woods include: such as Collins Guitars, Gibson Guitars, C. F. Martin \& Co., Ramsey Guitars, Manuel Rodriguez Jr, and Walden Guitars.

[40] Juszkiewicz, Henry. 2011. Gibson Guitar Corp. Responds to Federal Raid. Gibson News-Lifestyle.http://www.gibson.com /News-Lifestyle/News/en-us/gibson-0825-2011.aspx (Accessed April 13, 2016).

[41] United States International Trade Commission. 2008. Wood Flooring and Hardwood Plywood: Competitive Conditions Affecting the U.S. Industries, August, Investigation No. 332-487.https://www.usitc.gov/publications/332/pub4032.pdf. Accessed April 13, 2016.

[42] Some recent examples of such approaches may be found in Biersack A and J. Greenberg, eds. 2006. Reimagining political ecology: Culture/power/history/nature. Durham, NC: Duke University Press; Carrier J. 2010. Protecting the environment the natural way: Ethical consumption and commodity fetishism. Antipode 42(3): 672-689. Klooster D .2010. Standardizing sustainable development? The Forest Stewardship Council's plantation policy review process as neoliberal environmental governance. Geoforum 41: 117-129. Dove M. 2011. The Banana Tree at the Gate: A History of Marginal Peoples and Global Markets; Borneo. New Haven, CT: Yale University Press; Hardin R. 2011. Concessionary politics: Property, patronage, and political rivalry in Central African forest management. Current Anthropology 52(3): S113-S125; Peet R, Robbins P and Watts M (eds) .2011. Global Political Ecology. London: Routledge; Weaver, T., J. Greenberg, W.L Alexander, A.-Browning-Aiken, eds. 2012. Neoliberalism and Commodity Production in Mexico. Boulder: University of Colorado Press; CT: Yale University Press.

[43] Martinez-Reyes, Jose. 2015. Mahogany intertwined: Enviromateriality between Mexico, Fiji, and the Gibson Les Paul Journal of Material Culture. pp.1-17. 